\title{
Against False Settlement: Designing Efficient Consumer Rights Enforcement Systems in Europe ${ }^{1}$
}

\author{
HORST EIDENMÜLLER ${ }^{*}$ AND MARTIN ENGEL
}

With its recent legislation on consumer $A D R$ and $O D R$, the European Union (EU) pioneers the creation of a comprehensive out-of-court dispute resolution system for B2C conflicts. The proposed system raises questions as to how consumer rights can and should be efficiently enforced. We propose design principles for efficient consumer rights enforcement systems in Europe and sketch an appropriate judicial model procedure. Against this background, we critique the new EU system: mandatory consumer rights will not be fully enforced; traders will have inefficient behavioral incentives; fundamental due process values will be compromised; an unnecessary, heavily regulated and costly private enforcement industry needs to be created; access to the courts for consumers will be seriously impaired. Mandatory consumer rights attempt to correct market failure. Such rights should be enforced in streamlined small stakes proceedings by state courts, not by private service providers.

\section{INTRODUCTION}

Consumer satisfaction has now been at the core of EU legal policymaking for more than a decade. With ever more information duties for traders, withdrawal rights for consumers, the policing of standard contract

* Dr. Horst Eidenmüller, LL.M. (Cantab.), is a Professor of Private Law and German, European and International Company Law at the University of Munich, Visiting Professor at the University of Oxford, and ECGI Research Associate. He has extensive experience as a mediator and arbitrator in national and international commercial conflicts.

${ }^{* *}$ Dr. Martin Engel, LL.M. (Stanford), is a Postdoctoral Researcher at the Center for International Law at the University of Munich. He also practices as a lawyer, collaborative lawyer, and mediator

1 The authors thank the participants of the EUI Conference on "The Transformation of Enforcement" in Florence (June 27-28, 2013), the participants of the University of Frankfurt Conference on "Alternatives to FormalizationFormalization of Alternatives?" in Frankfurt (July 20-21, 2013) as well as the participants of the University of Amsterdam Conference on "Private Law and the Basic Structure of Society" in Amsterdam (January 31, 2014) for their feedback and discussions. 
terms in B2C contracts, and mandatory substantive consumer protection rules regarding sales and service contracts, the European Commission (Commission) tries to support consumer confidence and boost the single market. According to this program, barriers to Union-wide trade are to be eliminated step-by-step until contracting with parties from other Member States becomes as easy as contracting in domestic commerce. ${ }^{2}$

Whereas the EU has, for a long time, focused on strengthening substantive consumer rights, it appears that only quite recently did it come to the Commission's attention that, according to Holmes' famous "acid test,"3 for consumer rights to be effective, there must be effective sanctions if such rights are not respected. And since most consumers are not jurists, the enforcement mechanism must be easily manageable for the layperson if the consumers themselves - as opposed to legal professionals-are supposed to use it. It is not the fuss that can be expected to meet the requirements of the forum; rather, the forum has to be fitted to the fuss. ${ }^{4}$

Very much in this spirit, the most recent consumer protection legislation in the $\mathrm{EU}$ focuses on designing efficient consumer rights enforcement mechanisms in Europe. ${ }^{5}$ With its Directive on Consumer Alternative Dispute Resolution (ADR) and its Regulation on Consumer Online Dispute

${ }^{2}$ See Communication from the Commission to the European Parliament, the Council, the European Economic and Social Committee and the Committee of Regions on Cross-Border Business to Consumer e-Commerce in the EU, at 16 \& 47, COM (2009) 557 final (October 22, 2009), available at http://ec.europa.eu/consumers/ strategy/docs/COM_2009_0557_4_en.pdf. However, it is important to note that the law is not the only barrier to cross-border shopping. Transaction (shipping) costs, in particular, are not taken into account by Eurobarometer but most likely create a notable obstacle to cross-border trade. Their relative weight is significant, especially in cases with a low transaction value.

${ }^{3}$ Oliver Wendell Holmes, The Path of the Law, 110 HARV. L. REV. 991, 995 (1997).

4 Frank E. A. Sander \& Stephen B. Goldberg, Fitting the Forum to the Fuss: A UserFriendly Guide to Selecting an ADR Procedure, 10 NEGOT. J. 49 (1994). See also Christian Duve ET AL., MEDIATION IN DER WIRTSCHAFT 351-53 (2d ed. 2011).

5 See EU Justice Scoreboard: A Tool to Promote Effective Justice and Growth, COM (2013) 160 final (March 27, 2013), available at http://ec.europa.eu/justice/ effectivejustice/files/justice_scoreboard_communication_en.pdf; Eric Dubois, Christel Schurrer \& Marco Velicogna, The Functioning of Judicial Systems and the Situation of the Economy in the European Union Member States, at 638 (Jan. 15, 2013), available at http://ec.europa.eu/justice/effective-justice/files/cepej_study_justice__scoreboard_en.pdf; Burkhard Hess, Study No. JAI/A3/2002/02 On Making More Efficient the Enforcement of Judicial Decisions Within the European Union (Feb. 18, 2004), available at http://ec.europa.eu/civiljustice/publications/docs/enforcement_judicial_decisions_180204_en .pdf. 
Resolution (ODR), ${ }^{6}$ the EU aims to provide a feasible and easily accessible framework within which consumers can pursue their rights quickly and effectively. ${ }^{7}$ Through a network of extra-judicial conciliation bodies and an EU online conflict allocation scheme, consumer disputes shall be resolved speedily and in a cost-efficient manner. However, the newly envisaged EU landscape for the resolution of small-stakes B2C disputes has the effect of sidelining state courts. Specifically, conflicts are shifted to private or semiprivate service providers who supposedly follow the consumers' interests by putting efficiency above judicial scrutiny and the observance of due process standards.

This paper argues that this is a detrimental development. The "settlement euphoria" that inspires the European push towards a non-judicial dispute resolution landscape is misguided on both justice and efficiency grounds. It is simply contradictory to set up a sophisticated system of mandatory consumer protection rights and to then leave the "enforcement" of these rights to non-legal private providers, which are not trained or incentivized for this task and which operate outside the procedural safeguards of the court system. To put it differently: mandatory consumer protection rights attempt to correct market failure. Hence, enforcing these rights should not be returned to the market. This move is also inefficient because "false settlement" compromises proper behavioral incentives for businesses. Further, a new and heavily regulated private enforcement architecture alongside the state courts would undoubtedly significantly increase the total transaction costs of the dispute system. Finally, even if ADR decisions are non-binding on the consumer, access to the courts will be at least de facto considerably impaired. Instead, consumer rights should be enforced in streamlined court proceedings specifically designed to meet the requirements

${ }^{6}$ Council Directive 2013/11, Alternative Dispute Resolution for Consumer Disputes and Amending Regulation (EC) No 2006/2004 and Directive 2009/22/EC, 2013 O.J. (L 165) 63 (EU) [hereinafter Directive on Consumer ADR]; Commission Regulation 524/2013, Online Dispute Resolution for Consumer Disputes and Amending Regulation (EC) No 2006/2004 and Directive 2009/22/EC, 2013 O.J. (L 165) 1 (EU) [hereinafter Regulation on Consumer ODR].

${ }^{7}$ See Directive on Consumer ADR, supra note 6, at 1; Regulation on Consumer ODR, supra note 6 , at 2 . 
of B2C disputes arising from small-stakes ${ }^{8}$ sales or service contracts in particular. ${ }^{9}$

This article starts with describing current developments in the field of consumer behavior, consumer law, and the institutional handling of consumer conflicts (section II). On this basis, the paper discusses fundamental principles of dispute systems design for efficiently enforcing consumer rights (section III) and attempts to develop a coherent model for an efficient consumer rights dispute system regarding small-stakes B2C transactions (section IV). This in turn leads to a critique of the recent EU legislation on consumer ADR and ODR (section V). The final section concludes and summarizes the main results of the paper (section VI).

\section{The CASE For Consumer Rights Dispute Systems Design}

Dispute systems design has a long tradition, especially in the United States of America. It deals with adapting the design of a certain conflict resolution procedure to the needs of its users. ${ }^{10}$ It tries to do this by establishing rules, principles, or institutions that, taken together, allow a systematic management of a specific type of conflict. By shifting its regulatory focus from the substantive rights of consumers to the procedural framework for handling $\mathrm{B} 2 \mathrm{C}$ conflicts, the $\mathrm{EU}$ enters the domain of consumer rights dispute systems design.

${ }^{8}$ We will assume that small-stakes disputes are cases in which the amount in dispute is lower than $€ 1,000$.

9 This is also one of the core recommendations drawn from the so-called Oxford Study. See Christopher Hodges \& Stefan Vogenauer, European Civil Justice Systems: Findings of a Major Comparative Study on Litigation Funding and Costs, FOUND. FOR L., JuST. \& Soc'Y 9 (Sept. 28, 2010), http://www.fljs. org/sites/www.fljs.org/files/public ations/Hodges.pdf.

10 See William Ury et Al., Getting DisPutes Resolved: Designing Systems to CUT THE COSTS OF CONFLICT passim (2d ed. 1993). See also DUVE ET AL., supra note 4, at 325; Lisa B. Bingham, The Next Step: Research on How Dispute System Design Affects Function, 18 NEGOT. J. 375 (2002); Horst Eidenmüller \& Andreas Hacke, Institutionalisierung der Mediation im betrieblichen Konfliktmanagement, PersonalfüHRUNG 20 (2003); Frank E. A. Sander \& Lukasz Rozdeiczer, Matching Cases and Dispute Resolution Procedures: Detailed Analysis Leading to a MediationCentered Approach, 11 HARV. NEGoT. L. REV. 1 (2006); Andrea Kupfer Schneider, Building a Pedagogy of Problem-Solving: Learning to Choose Among ADR Processes, 5 HARV. NEGOT. L. REV. 113 (2000). 


\section{A. Recent Developments in Consumer Behavior and Consumer Law}

The current European legislation for enforcing consumer rights and resolving B2C disputes follows a somewhat long-term and steady increase in cross-border e-commerce ${ }^{11}$ and, consequently, in cross-border consumer disputes. With the rise of the Internet, many consumers have learned to shop online in a sophisticated manner and to exploit differences in price. ${ }^{12}$ They have also gained access to products and services that were previously unavailable to them. Today, for numerous consumers, national borders play only a secondary role in the selection of a contract partner. With growth rates clearly in the double-digit area per year, e-commerce, since the turn of the millennium, is among the fastest growing sectors of the European economy, and there are no signs that this trend might reverse in the foreseeable future-quite the contrary. ${ }^{13}$

Coinciding with this development, the EU has taken significant steps to boost consumer confidence even further by setting up a comprehensive and mandatory system of consumer rights in $\mathrm{B} 2 \mathrm{C}$ transactions. These include farreaching information duties for businesses, the policing of standard contract terms, rules on product and service quality, remedies for breach of contract, and withdrawal rights. Many of these rights are ineffective, inefficient, and redistribute between consumer segments. ${ }^{14}$ This has not stopped the EU from pushing full force in the direction of ever more consumer protectionliterally at all costs. The current acquis communautaire, the Common Frame

11 Since the turn of the millennium, cross-border online shopping within the EU has notably increased. One in ten EU consumers (10\%) purchased online from a seller/provider in another EU country in 2011/2012 compared with 6\% in 2006. Consumers' Attitudes Towards Cross-Border Trade and Consumer Protection, at 6, FLASH EUROBAROMETER (2012) final 332, (June 2012) [hereinafter FlaSH EUROBAROMETER 332].

$1256 \%$ of EU citizens with Internet access have in the 12 months before the survey purchased goods or services online. FLASH EUROBAROMETER 332, supra note 11, at 11.

13 Of all cross-border purchases, the ratio of online business was $18 \%$ in 2002 , rising to $27 \%$ in 2006 , and reaching $46 \%$ in 2011 ; FLASH EUROBAROMETER 332, supra note 11 , at 14. See Public Opinion in Europe: Views on Business-to-Consumer Cross-Border Trade, at 7, FLASH EUROBAROMETER (2002) final 128 (Nov. 14, 2002).

${ }^{14}$ See Horst Eidenmüller et al., Towards a Revision of the Consumer Acquis, 48 COMMON MKT. L. REV. 1077 (2011); Horst Eidenmüller, Why Withdrawal Rights?, 7 EUR. REV. CONT. L. 1, 5 (2011). 
of Reference (CFR), ${ }^{15}$ and the Draft Common European Sales Law (DCESL) proposed in $2011,{ }^{16}$ reflect the EU's legal policy in this respect over the past two decades. On the level of private international law, Article 6(2) of the Rome I Regulation has also been designed to ease cross-border trade as it assures the consumer that he will usually be guaranteed, at a minimum, the consumer protection level of his home state. Hence, the consumer can conduct transactions in any Member State without having to be concerned with the respective substantive law.

\section{B. The Current State of Judicial Consumer Rights Enforcement}

However, the concept of boosting cross-border trade and the single European market by mandatory rights of consumers and by (minimum) harmonization of the European Member States' laws in this respect, comes with an important caveat: as second year law students learn all over the world, the value of a right depends heavily on the mode of its enforcement and, in particular, the costs associated with this enforcement. This turns the attention to the question concerning the extent to which consumer rights in small-stakes cases are nowadays effectively enforced in the EU.

Rights enforcement is first and foremost the task of the public courts. Most European Member States allow small-stakes claims to be brought to local courts whose jurisdiction depends on a claim value lower than a certain amount, e.g., $€ 5,000$ in Germany. ${ }^{17}$ Furthermore, many Member States do

15 For the latest developments as to the Common Frame of Reference see Health and Consumers, EUR. COMM'N, http://ec.europa.eu/health_consumer/index_en.htm (last visited Mar. 28, 2014). For the academic Draft Common Frame of Reference (DCFR) see Christian von Bar ET AL., STUdy Group ON A EUROPEAN Civil CODE \& RESEARCH Group on EC PRIVATE LAW, PRINCIPLES, DEFINITIONS, AND MODEl RULES OF EUROPEAN PrIVATE LAW (2009), available at http://ec.europa.eu/justice/policies/civil/docs/ dcfr_outline_edition_en.pdf. See also Horst Eidenmüller et al., The Common Frame of Reference for European Private Law - Policy Choices and Codification Problems, 28 OXFORD J. LEGAL STUD. 659 (2008).

16 Proposal for a Regulation of the European Parliament and of the Council on a Common European Sales Law, COM (2011) 635 final (Oct. 11, 2011), available at http://eur-lex.europa.eu/LexUriServ/LexUriServ.do?uri=COM:201 1:0635:FIN:en:PDF.

See also Horst Eidenmüller et al., The Proposal for a Regulation on a Common European Sales Law: Deficits of the Most Recent Textual Layer of European Contract Law, 16 EDINBURGH L. REV. 301 (2012); Eidenmüller et al., supra note 14, at 1077.

17 Gerichtsverfassungsgesetz [GVG] [Courts Constitution Act], May 9, 1975, RGBL. I at 1938, as amended, $\S 23(1)$ (Ger.). In England and Wales, small claims courts handle cases up to a value of $£ 10,000(\approx € 11,700)$, whereas Danish small claims courts' jurisdiction is restricted to a maximum amount in dispute of DKK $50,000(\approx 66,700)$. 
not require parties to be represented by an attorney before such courts. ${ }^{18}$ In 2006 and 2007, the EU itself established a European order for payment procedure and a small claims procedure for claims with a value of up to $€ 2,000$, which apply to all Member States except Denmark. ${ }^{19}$ The goal is to make 'access to justice' a reality even for low-value claims. At the same time, reforms that have made the right to file a claim dependent on a previous unsuccessful settlement attempt or mediation have been repealed in many Member States-sometimes because such reforms were deemed unconstitutional for limiting parties' access to the courts. ${ }^{20}$

Even though Member States have made considerable advances to ease access to their respective small claims courts, the caseload of these courts is steadily decreasing. In Germany, for example, the caseload of the local small claims courts (Amtsgerichte) has declined continuously by more than $2 \%$ per

Lower maximum thresholds can be found in Northern Ireland and Scotland ( $£ 3,000 \approx$ $€ 3,500)$, Ireland $(€ 2,000)$, and Spain $(€ 900)$. In the United States, maximum amounts in dispute also vary: for example, California small claims courts handle cases up to $\$ 5,000$ amount in dispute, while Illinois applies a maximum amount of $\$ 10,000$.

18 For example, Germany (ZIVILPROZESSORDNUNG [ZPO] [CODE OF CIVIL Procedure], Dec. 5, 2005, RGBL. I 3533, AS AMENDED, $\S 78$ ), France (CODE DE Procédure Crvil [C.P.C.] art. 827), and the United Kingdom (customary right to selfrepresentation) do not require parties to be represented by an attorney. In some small claims courts in the U.S., such as in California (CAL. CIV. PROC. CODE $§ 116.530$ ), it is even forbidden to be represented by a lawyer in a small claims procedure.

19 The European order for payment procedure was established by Regulation (EC) No 1896/2006. Xandra Kramer provided a first evaluation. Xandra E. Kramer, Enhancing Enforcement in the European Union: The European Order for Payment Procedure and Its Implementation in the Member States, Particularly in Germany, the Netherlands, and England, in ENFORCEMENT AND ENFORCEABILITY-TRADITION AND REFORM 17 passim (Cornelis H. van Rhee \& Alan Ucelac eds., 2010). The European small claims procedure was established by Council Regulation 861/2007, 2007 O.J. (L 199) (EC). See JULES STUYCK ET AL., AN ANALYSIS AND EVALUATION OF ALTERNATIVE MEANS OF CONSUMER Redress Other than Redress Through ORDINARy Judiclal Proceedings (2007), available at http://ec.europa.eu/consumers/redress/reports_studies/comparative_ report_en.pdf; Georg Haibach, The Commission Proposal for a Regulation Establishing $\bar{a}$ European Small Claims Procedure: An Analysis, 13 EUR. REV. PRIVATE L. 593 (2005).

20 In Italy, the Corte Costituzionale (judgment dated October 24, 2012, file no. 272/2012) struck down the statutory mediation requirement in late 2012; however, its reintroduction was enacted in June 2013. Corte Cost., 24 ottobre 2012, n. 272 (It.) For a critical analysis, see Giuseppe De Palo \& Lauren R. Keller, The Italian Mediation Explosion: Lessons in Realpolitik, 28 NEGOT. J. 181 (2012). In Germany, most states (Länder) have cut back the statutory requirement for smallest-stakes claims (amount in dispute lower than $€ 750$ ) to be conciliated or mediated before they can be brought to court. EINFÜHRUNGSGESETZ ZPO [EGZPO] [INTRODUCTORY LAW OF CIVIL PROCEDURE], Aug. 31, 2013, RGBL. I at 3533, § 15 a. 
year over the last ten years-despite significant GDP growth rates. ${ }^{21}$ The situation in other Member States is not different. ${ }^{22}$ An explanation for this phenomenon could be that there are fewer and fewer small-stakes contracts or at least fewer and fewer conflicts arising out of these contracts. Both conjectures, however, are highly implausible. It seems much more likely that the transaction costs associated with going to court are prohibitively high for many consumers, and increasingly so: consumers have to spend a three-digit amount in court fees for most claims no matter how low the amount in dispute happens to be. ${ }^{23}$ Consumers are mostly wary of bringing suit without a lawyer, which generates expensive legal costs, and a significant amount of time is also invested in preparation, i.e., opportunity costs are incurred that will often far exceed the amount in dispute. ${ }^{24}$ Hence, using existing state court proceedings to solve these disputes seems to become increasingly inefficient.

The situation is even more problematic for distance transactions in general, and cross-border cases in particular. Here, the geographical distance between at least one party and the competent court, language differences, and a lack of knowledge as to the applicable substantive law pose major obstacles that trigger even higher transactions costs for resolving disputes through the court system. No one, for example, will seriously consider suing a trader located in another Member State 1,000 miles away for a defective Blu-ray player bought over the Internet for $€ 100$. It cannot be denied that this negatively impacts on trade and economic growth if no other efficient consumer rights enforcement and dispute resolution mechanisms are available.

21 Destatis, FACHSERIE 10, REIHE 2.1, RECHTSPFLEGE: ZIVILGERICHTE 12 (2012), available at https://www.destatis.de/DE/Publikationen/Thematisch/Rechtspflege/Gerichte Personal/Zivilgerichte2100210117004.pdf?_blob=publicationFile.

22 In the United Kingdom, the number of small claims hearings decreased by almost one third within a decade, according to the Ministry of Justice. MINISTRY OF JUSTICE, JUDICIAL AND COURT STATISTICS 17 (2011). A study on statistics of US small claims courts in 28 states showed an average 14\% decrease in caseload between 2008 and 2010. See National Center for State Courts, Small Claims Fall Sharply in Last Two Years, CT. STAT. (last visited May 12, 2013), http://www.courtstatistics.org/Civil/2012W5CIVIL. aspx.

23 Under German law, for example, since 2013 even claims amounting to $€ 1$ or less result in court fees of more than $€ 100$. GERICHTSKOSTENGESETZ [GKG], May 5, 2004, as amended, $\S \S 3,34$, app. 1 No. 1210.

24 Only about one third of EU customers agree that it is easy to resolve disputes with sellers/providers through the courts. See FLASH EUROBAROMETER 332, supra note 11, at 118. 


\section{The Emergence of Private Competition for Consumer Rights Enforcement}

The described deficits of state court proceedings trigger the search for public and private alternatives to the current small claims court system. In the past couple of years, various new forms of dispute resolution proceedings have emerged and have taken a significant market share from the public courts. These proceedings and schemes can be classified in various ways, such as who operates them, who provides funding, what their resolution standard is, what type of decision is issued, and what kind of technology is employed.

\section{Operators}

As to the operators of new dispute resolution mechanisms, some are state-run, but most are administered by private providers. There have been some attempts to establish electronic courthouse systems. In 2002, the state of Michigan in the United States, for example, decided to set up a civil cyber court for certain disputes with a claim value over $\$ 25,000$; however, the project failed to take off and was eventually abandoned ten years later. ${ }^{25}$ The Singapore Supreme Court had more staying power. Today, it hosts five socalled Technology Courts-courtrooms that are specially equipped with videoconferencing technology, even though the hearing itself will still take place in the real courtroom. ${ }^{26}$ However, the payable fees easily exceed $\$ 1,000$, which makes these courts unattractive for handling small stakes disputes. The first real cyber court still has not been opened, so whatever states have done to modernize their judiciary looks more like a slight update than a real systemic alternative.

In many European Member States, consumer organizations play a significant role in ensuring effective consumer protection. However, the use of innovative dispute resolution schemes is still rare. ${ }^{27}$ Several Union-wide

25 See Lucille M. Ponte, The Michigan Cyber Court: A Bold Experiment in the Development of the First Public Virtual Courthouse, 4 N.C. J. L. \& TECH. 51 (2002).

26 See Supreme Court Singapore, TECH. CT., http://app.supremecourt.gov.sg/ default.aspx?pgID=57 (last updated June 10, 2013), .

${ }^{27} \mathrm{~A}$ recent example is the German service http://www.online-schlichter.de; however, its code of procedure is quite taciturn as to the core decision mechanism. The Belgian Federal Government has set up the "BelMed" platform, which is unfortunately accessible only after setting up a personal account. See Belmed, ECONOMIE: BELG. FED. Gov'T, http://economie.fgov.be/en/disputes/consumer_disputes/Belmed/ (last visited 
clearinghouses and complaint platforms set up a decade ago have not been a success. ${ }^{28}$ In Canada and the United States, consumer organizations tend to be more inclined towards innovative use of technology; here, a number of online consumer complaints systems are already at work and handle a remarkable caseload. ${ }^{29}$

In the meantime, private providers have been less reluctant in leading the way for alternative procedures. Sometimes, businesses themselves have set up dispute resolution services for their clients. Those systems were pioneered by eBay and PayPal, which were the first to create a comprehensive problem solution tool ${ }^{30}$ eBay in particular experimented with a Community Court, which was run by experienced users. ${ }^{31}$ Later on, eBay turned to providing a fully automatic case manager facilitating communication between traders and consumers, and only highly problematic cases were referred to the company's

May 12, 1024); Stefaan Voet, Belmed: The Belgian Digital Portal for Consumer $A(O) D R$, SSRN (Apr. 6, 2013), http://ssm.com/abstract_id=2245017; Stefaan Voet, in CONSUMER ADR IN EUROPE 26 (Christopher Hodges et al. eds., 2012).

28 The most prominent of those rarely used platforms were ECC-Net, FIN-NET, and SOLVIT. See Iris Benöhr, in CONSUMER ADR IN EUROPE 13 (Christopher Hodges et al. eds., 2012).

${ }^{29}$ See, e.g., CONSUMER PROTECTION BC, http://www.consumerprotectionbc.ca/odr (last visited Mar. 28, 2014). See also What Complaints Do We Handle?, BETTER BuS. BUREAU, https://www.bbb.org/consumer-complaints/file-a-complaint/get-started (last visited Mar. 28, 2014) (providing an online complaint form. Statistics for the mentioned BBB tool show more than 844,000 complaints in the US for 2010 alone).

30 eBay customers facing problems with their transaction are encouraged to first contact the contracting partner and, if this does not solve the problem, open a case at the eBay Resolution Center at http://resolutioncenter.ebay.com. If the other party does not show a reaction on the following communication request, the customer can escalate the case to eBay Customer Support. She might qualify for the so-called eBay Buyer Protection, an eBay-internal insurance. PayPal runs a similar Resolution Center. See The PayPal Resolution Center: Your Place to Solve Transaction Disputes, PAYPAL, https://www.paypal.com/cgi-bin/webscr?cmd=xpt/cps/general/PPDisputeResolutionoutside (last visited Mar. 28, 2014).

${ }^{31}$ In the eBay Community Court, a jury composed of experienced eBay users decided on cases concerning seller complaints about negative feedback from buyers. See Colin Rule, Making Peace on eBay: Resolving Disputes in the World's Largest Marketplace, AC RESOL. MAG., Fall 2008, at 8; Colin Rule \& Chittu Nagarajan, Leveraging the Wisdom of Crowds: The eBay Community Court and the Future of Online Dispute Resolution, AC RESOL. MAG., Winter 2010, at 4. Criticisms as to the fairness of this dispute resolution scheme are raised by Jaap van den Herik \& Daniel Dimov. See Jaap van den Herik \& Daniel Dimov, Can the eBay's Community Review Forum Fairly Resolve Disputes, 4 PROC. 23RD BENEluX CONF. ON ARTIFICIAL INTElligenCE 263 (2011). 
customer service. ${ }^{32}$ In many European Member States, business associations, and chambers of commerce have developed out-of-court dispute resolution systems for their member companies. The most visible of these are ombudsmen; for example, for financial investment issues, insurance claims, health care services (existing in several Member States), furniture sales (UK), legal services, general consumer affairs (Norway and Denmark), or Internet issues (Austria). ${ }^{33}$

Finally, a variety of innovative dispute resolution mechanisms have been created by independent private providers, such as cybersettle.com, ${ }^{34}$ smartsettle.com, juripax.com, justiceonline.com.sg, and recently modria.com. Making use of Internet technology and software tools, these providers offer companies the opportunity to outsource their claims management in order to keep control of litigation risk and enhance consumer satisfaction. Some businesses even see sound dispute management as an essential element of a high-service brand, ${ }^{35}$ which is perfectly reasonable as consumers tend to accept the occasional occurrence of material defects, ${ }^{36}$ but care a lot about how traders handle their complaints. ${ }^{37}$

32 The eBay Community Court was redesigned as a Community Review Forum in early 2011 and not long afterwards closed (in early 2012) due to the bundling of dispute resolution services in the eBay Resolution Center.

33 For example, the German Insurance Ombudsman scheme has been in place since 2002. It is operated and completely financed by a registered association whose members (German insurance companies) accept decisions up to a value in dispute of $€ 10,000$ to be unilaterally binding on them. See VERFAHRENSORDNUNG DES VERSICHERUNGSOMBUDSMANNS [VOMVO], Nov. 21, 2013, § 11 [hereinafter VOMVO]. Currently, the ombudsman office is held by a former president of the German Federal Supreme Court. Statistics show a remarkable caseload of 17,263 cases filed in 2012 and an average duration of proceedings of 3 months. See OMBUDSMANN FÜR VERSICHERUNGEN, JAHRESBERICHT $2012 \quad 78$ (2012), available at http://www.versicherungsombudsmann.de/Ressourcen/PDF/Jahresbericht-2012.pdf.

Regarding the typical procedure of an ombudsman scheme, see Brian Bloch et al., Systems for Dealing with Conflict and Learning from Conflict-Options for ComplaintHandling: An Illustrative Case, 14 HARv. NEGOT. L. REV. 239 (2009).

${ }^{34}$ Still in 2012, cybersettle.com advertised having settled more than 200,000 disputes at a total value of $\$ 1.6$ billion; as of today, they have changed their business model to offering claims management for health care bills.

35 Johanna Stark \& Martin Engel, The CESL as a European Brand, in REGULATORY COMPETITION IN CONTRACT LAW AND DISPUTE RESOLUTION 337, 339 (Horst Eidenmüller ed., 2013).

36 Ana Belén del Río-Lanza et al., Satisfaction with Service Recovery: Perceived Justice and Emotional Responses, 62 J. BUS. RES. 775 (2009).

${ }^{37}$ Mary A. Konovsky, Understanding Procedural Justice and Its Impact on Business Organizations, 26 J. MGMT. 489 (2000). 


\section{Financing}

A second distinct characteristic of the new alternative resolution schemes is their source of funding. Schemes operated by businesses themselves such as the PayPal Resolution Center are usually financed by the company itself. Additionally, dispute resolution tools provided by trading platforms such as eBay Buyer Protection usually do not charge the customer party a procedural fee. If it is a business association, trade chamber, or other interest group that operates the conciliation body, the consumer will usually be charged not more than a nominal fee as a safeguard against abusive claims. For example, most ombudsman schemes are run free of charge and financed by business associations and trade chambers in order to encourage consumers to file their cases using such schemes instead of pursuing claims in a public court. ${ }^{38}$

Of course, via the pricing mechanism, the costs for operating the settlement services are borne by the consumers as a group anyway. More specifically, all consumers contribute to financing a resolution scheme that only a subgroup will use. By contrast, with the public court system, it is predominantly those who use it who must pay for it. ${ }^{39}$ Hence, even if it is only the public courts that directly charge its users, it is always necessary to consider whether dispute resolution services are worth the associated costs, regardless of who pays for them in the first place. There is no such thing as a free lunch, and this equally applies to consumer dispute resolution.

\section{Resolution Standard}

Another analytical heuristic that differentiates consumer dispute resolution schemes is the resolution standard used. From the perspective of dispute systems design, it makes a crucial difference whether conflict resolution aims at enforcing consumer rights, satisfying the parties' interests, enhancing consumer satisfaction, or pursuing any other conceivable aim as a resolution standard.

38 See, e.g., VomVO, supra note 33, at § 14; Austrian Internet Ombudsman, OMBUDSMANN, http://www.ombudsmann.at/schlichtung.php/cat/2/title/So_funktioniert \%27s\#a5 (last visited Mar. 28, 2014); UK Legal Ombudsman, LEGALOMBUDSMANN, http://www.legalombudsman.org.uk/aboutus/ (last visited Mar. 31, 2014); UK Glazing Ombudsman, GLAZING OMBUDSMAN, http://www.glazingombudsman.com/home/ consumer (last visited Mar. 28, 2014).

${ }^{39}$ Costs are spread to the general taxpayer only to the extent that court fees (in small claims cases) do not cover the full costs of the proceedings. Further exceptions are cases financed through legal aid. Legal aid grants are not unusual for small claims, but they are predominantly awarded in family disputes rather than in sales law cases. 
Alternative dispute resolution schemes that aim at a consensual dispute settlement frequently place an emphasis on interests, rather than on the positions of the parties or on the rights asserted. ${ }^{40}$ By contrast, court proceedings, as well as ombudsman services, typically claim to base their decisions on consumer rights on the law. ${ }^{41}$ It is important to be as clear as possible on this issue. If, next to consumer rights enforcement, consumer satisfaction is stated to be an important goal, ${ }^{42}$ evaluating the performance of the provider is possible only if a meaningful way of assessing such satisfaction is suggested, the relevant data collected, and the results published.

\section{Resolution Type}

Another crucial factor distinguishing various dispute resolution mechanisms is the type of conflict resolution provided. Whereas state courts mostly encourage settlement but, if the parties do not settle, eventually hand down a binding decision; alternative dispute resolution schemes sometimes also yield a binding decision, e.g., arbitration, but, at other times, do not. This is true, for example, with respect to mediation and collaborative law. In other cases, such alternative schemes result in a hybrid between consensus and third-party decision, such as a semi-binding or preliminary judgment.

The most established example of an entity issuing semi-binding decisions is the ombudsman scheme. Here, the "judgment" is often binding only on the business involved but not on the consumer. For example, German insurance companies subject themselves to the decision of their association ombudsman up to a claim value of $€ 10,000.43$ Hence, there seems to be a great option value for consumers in initiating a case with the ombudsman: the procedure is free of charge, and, if they win, the outcome is binding on the counterpart; if they lose, they can still bring suit in a public court. However, consumers in general do not fight an adverse ombudsman decision

${ }^{40}$ For the difference between positions, interests, and the method of 'principled negotiation,' see ROGER FISHER ET AL., GETTING TO YES 40 passim (2d ed. 1981).

${ }^{41}$ For example, the Danish Consumer Ombudsman claims to ensure compliance with the Danish Marketing Practices Act and the principles of fair marketing practices in general. See Danish Consumer Ombudsman, CONSUMER OMBUDSMAN, http://www.consumerombudsman.dk/About-us/introduction (last visited Mar. 28, 2014).

42 See Pablo Cortés, Online Dispute Resolution for CONSUMERS IN THE EUROPEAN UNION 3 (2011); FRANK ALLEWELDT ET AL., FINAL REPORT TO DG SANCOSTUDY ON THE USE OF Alternative DiSPUTE RESOlUTION IN THE EUROPEAN UNION 151, 163 (2009).

43 VoMVO, supra note 33, at $\S 10(3), 11$. 
before the public courts because of the high costs associated with court proceedings. ${ }^{44}$ Hence, in general, ombudsman decisions also are at least de facto binding on consumers.

\section{Technology}

Finally, alternative dispute resolution schemes can be distinguished on the basis of the technology employed. There exist online tools, offline procedures, and hybrids of both. Examples of online mechanisms are the private dispute resolution providers named above in section 1 . Offline systems are used mainly by state or semi-public providers such as the conciliation committees of local chambers of industry and commerce.

It appears that there is a recently emerging trend to switch to online dispute resolution procedures. Sure enough, online providers already surfaced some fifteen years ago, and many of them-such as cybersettle.com-have not maintained their original business model or have even completely disappeared from the market, e.g., Click'n'Settle. However, with companies such as eBay and PayPal providing an innovative, separate dispute resolution system, and with legislators becoming more ready to experiment with modern technology, ${ }^{45}$ the online dispute resolution industry seems to be gaining new ground. ${ }^{46}$ This is not surprising: For small-stakes distance transactions, online resolution clearly is the most efficient form of dispute settlement. ${ }^{47}$

44 The major cost driver for parties is the attorneys' fees. Certainly, in most Member States, there is no requirement to hire lawyers in order to file a small claim. However, parties rarely bring suit without a lawyer. This suggests that those who cannot afford or do not want to pay a lawyer do not bring suit and their cases remain untried by a public court. For example, in German small claims courts, the claimant is represented by an attorney in $87 \%$ of all cases (cases concluded in 2011). See DESTATIS, supra note 21, at 30 .

45 Katrina Fischer Kuh, Electronically Manufactured Law, 22 HARV. J.L. \& TECH. 223 (2008); Hanns Prütting, Auf dem Weg von der mündlichen Verhandlung zur Videokonferenz, 63 ANWALTSBLATT 330 (2013); Howard M. Wasserman, Orwell's Vision: Video and the Future of Civil Rights Enforcement, 68 MD. L. REV. 600 (2009). For a critical view, see Robert Hardaway et al., E-Discovery's Threat to Civil Litigation: Reevaluating Rule 26 for the Digital Age, 63 RUTGERS L. REV. 521 (2011).

46 The newly emerging services of modria.com, juripax.com, peopleclaim.com, and justiceonline.com.sg show the recent growth in the industry of dispute resolution providers.

${ }^{47}$ Apart from saving transaction costs, one crucial advantage of online dispute resolution procedures is that they avoid the emotion-driven inefficiencies sometimes associated with face to face negotiations. See Joseph B. Walther, Relational Aspects of 
Moreover, businesses nowadays seem to be quite willing to serve as the sole financier of dispute resolution services and are apparently unafraid of system abuse by consumers. Businesses can obviously live with third-party decisions that are only binding on them but not on consumers. This is because they know that there are enough obstacles the consumer will face before bringing a suit and because they appreciate the enhanced image that results from more consumer satisfaction-whatever that is exactly.

\section{Recent Legislation on Consumer Dispute Resolution}

Against this background of increasing numbers of distance contracts, systemic deficiencies in the European Member States' small claims procedures, and the rise of alternative forms of dispute resolution, regulators all over the world are attempting to modernize consumer dispute resolution processes.

\section{EU Legislation}

As already mentioned, the EU has recently passed a Directive on Consumer ADR and a Regulation on Consumer ODR in order to weave the newly emerging conflict resolution schemes into a comprehensive system of alternative dispute resolution for $\mathrm{B} 2 \mathrm{C}$ transactions.

The Directive aims to set up a network of locally available ADR entities to provide fast and low-cost dispute resolution for consumer conflicts arising out of sales and service contracts. ${ }^{48}$ Traders need not participate, but, as soon as they do, they must provide information on competent ADR entities on their homepage. ${ }^{49}$ The EU wants every consumer to know about this lowthreshold mechanism. ${ }^{50}$ At the same time, the Directive is not targeted at taking cases away from the public small claims courts, but at settling cases that now remain unresolved. ${ }^{51}$

Parallel to the ADR Directive, the Regulation on Consumer ODR enables the EU to set up a Union-wide online platform for consumers,

Computer-Mediated Communication: Experimental Observations over Time, 6 ORG. SCI. 186 passim (1995); CHRISTIAN BÜHRING-UHLE ET AL., VERHANDLUNGSMANAGEMENT 5 (2009).

48 Directive on Consumer ADR, supra note 6, at 70.

${ }^{49}$ Id. at 75-76.

${ }^{50} \mathrm{Id}$. at $67-68$.

${ }^{51} \mathrm{Id}$. at 68 . Whether consumers can be forced into a consumer ADR procedure in standard terms is another issue. On this issue, see $I d$. at 70,75 and see infra Part V.B.3. 
whereby consumers can easily obtain information on a competent ADR entity to handle their case and can immediately file an online complaint. ${ }^{52}$ Both regulations, together, aim to build a comprehensive out-of-court consumer dispute resolution framework ${ }^{53}$ to bridge the gap between direct negotiations between traders and consumers on the one hand, and the public courts on the other.

\section{United States Regulation}

While the attempt to establish a cyber court in the state of Michigan was eventually abandoned in 2012 , it is relevant to note that it would have only provided a framework for medium and large-stakes disputes. ${ }^{54}$ And yet, it might have served as a role model for a low-cost procedure for small claims, too. In any event, it seems unlikely that the technological build-up in US civil procedure will, in the medium term, exceed the scope of Federal Rule of Civil Procedure 43(a), which permits testimony by videoconferencing under certain circumstances. .55

However, in the wake of the latest financial crisis, there has been increased public awareness of particular consumer needs such as protection against fraudulent financial investment advice. In 2010, Sec. 1011 of the

52 This platform is quite similar to the one proposed by Robert C. Bordone, already fifteen years ago, which in turn referred to the famous (offline) multi-door courthouse idea, brought up by Frank E. A. Sander. Robert C. Bordone, Electronic Online Dispute Resolution: A Systems Approach-Potential, Problems and a Proposal, 3 HARV. NEGOT. L. REV. 175 passim (1998); Frank E. A. Sander, Varieties of Dispute Processing, 70 F. R. D. 79, 131 (1976). The similar attempt by UNCITRAL to establish an ODR procedure has not yet been completed. See Ronald A. Brand, Party Autonomy and Access to Justice in the UNCITRAL Online Dispute Resolution Project, 10 LOY. U. CHI. INT'L. REV. 11 (2012). See also Working Group Documents-Working Group III: 2010 to Present: Online Dispute Resolution, UNCITRAL, http://www.uncitral.org/uncitral/commission/ working_groups/3Online_Dispute_Resolution.html (last visited Apr. 14, 2014).

${ }^{53}$ See Regulation on Consumer ODR, supra note 6, at 4; Directive on Consumer ADR, supra note 6 , at 70 ("ensuring that consumers can . . submit complaints . . to entities offering ... alternative dispute resolution procedures.").

54 See Ponte, supra note 25.

55 This, however, already saves significant costs. For example, in Travis County, Texas, the so-called I-Jury Online Impaneling makes online answering of jury summons possible. This saves more than $\$ 100,000$ per year in jury costs as unnecessary physical appearances are avoided. It also reduces the number of summons and the number of scheduled impaneling sessions, saving more than $\$ 25,000$ per year in rent. See National Center for State Courts, TECH. CT., http://www.ncsc.org/Topics/Technology/ Technology-in-the-Courts/ResourceGuide.aspx (last visited Mar. 28, 2014). 
Dodd-Frank Act laid the foundation for the formation of the Consumer Financial Protection Bureau (CFPB) in mid-2011, a federal agency responsible for consumer protection in the field of financial products and services. Amongst other services, the CFPB enables consumers to submit an online complaint on any bank-related issue such as money transfers, loans, mortgages, credit cards, or credit reports. ${ }^{56}$ The difference between the CFPB complaint and the EU ODR complaint is, however, that the EU service will not be restricted to financial issues and will not handle the complaint itself, but rather simply forward it to a competent ADR entity. A similar service does not exist in the U.S. so far.

\section{Experience from Australia}

Apart from the U.S. and the EU, the country with the most significant experience regarding modern public small claims procedures is Australia. The Supreme Court of Victoria and the civil courts in Brisbane have experimented with facilitating court procedures through digital technology. However, the service currently provided is still restricted to comprehensive electronic document management support. ${ }^{57}$ Other countries have mimicked this approach and have started electronic case filing at least for the written proceedings. $^{58}$

For the time being, the efforts of public providers of innovative consumer dispute resolution have thus far been unsystematic. Legislators worldwide strive to make their judiciaries capable of competing with private dispute resolution providers. In order to avoid compromising fundamental due process values of civil procedure-while maintaining systemic coherence-there is a considerable need to define crucial principles of consumer rights dispute systems design for legislators to follow if they create new schemes of procedural consumer protection.

${ }^{56}$ See Submit a Complaint, CONSUMER Fin. Protection Bureau, $\mathrm{http}: / / \mathrm{www} . c 0 n s u m e r f i n a n c e . g o v / c o m p l a i n t /$ (last visited Mar. 28, 2014).

57 See, e.g., Electronic Trials (eTrials), QUEENSLAND CT., http://www.courts.qld.gov .au/information-for-lawyers/electronic-trials-etrials (last visited Mar. 28, 2014); E-Filing, SUP. CT. VICT., http://www.supremecourt.vic.gov.au/ home/courtroom+technology/ efiling (last updated July 30, 2013).

58 See, e.g., Stand der Informationtechnik in der Bayerischen Justiz, BAYERISCHES STAATSMINISTERIUM DER JUSTIZ UND FUER VERBRAUCHERSCHUTZ (June 2013), http://www.justiz.de/BLK/laenderberichte/bayern.pdf (the AUGEMA program facilitating the summons procedure in the central Bavarian court for decisions on summons in Coburg). 


\section{PRINCIPLES OF CONSUMER RIGHTS DISPUTE SYSTEMS DESIGN}

To outline principles of consumer rights dispute systems design is a prescriptive rather than a descriptive task. This task does not focus on what new developments in the field of consumer dispute resolution currently look like, but on how dispute systems should be designed and which maxims they should follow. The term 'principles' in this regard means objectives and quality criteria that shape the design of a dispute resolution system and, consequently, its functioning.

\section{A. Justice Criteria}

The first fundamental set of principles that consumer rights dispute systems must reflect relates to questions of justice. Here, 'justice' comprises enforcement of substantive consumer rights, respect for established due process values, and access to judicial proceedings.

\section{Consumer Rights Enforcement}

It is not a matter of course that the enforcement of substantive consumer rights is or should be one of the guiding principles of consumer dispute resolution procedures..$^{59}$ Consumer satisfaction ranks high in current legal policymaking. ${ }^{60}$ But while the meaning of this concept and its measurement are open to doubt, consumer satisfaction surely cannot be equated with the enforcement of consumer rights pure and simple. ${ }^{61}$

${ }^{59}$ Christopher Hodges, Collectivism: Evaluating the Effectiveness of Public and Private Models for Regulating Consumer Protection, in COLLECTIVE ENFORCEMENT OF CONSUMER LAW 205, 207 (Willem van Boom \& Marco Loos eds., 2007) (contends that "the primary focus now is on improving the ability of consumers to realise their rights"). For a different focus, see Linda Mulcahy, The Collective Interest in Private Dispute Resolution, 33 OXFORD J. LEGAL STUD. 59 passim (2013) (who emphasizes the value of precedence and of the collective interest in private adjudication).

${ }^{60}$ See, e.g., IPSOS INRA, Consumer Satisfaction Survey, passim (May 2007), available at http://ec.europa.eu/consumers/cons_int/serv_gen/cons_satisf/consumer_ service_finrep_en.pdf; Memorandum 11/718 from Eur. Comm'n, Making Markets Work For Consumers: Questions and Answers on the 2011 Consumer Markets Scoreboard 6 (Oct. 21, 2011), available at $\mathrm{http} / / /$ europa.eu/rapid/press-release_MEMO-11-718_en.pdf.

${ }^{61}$ According to Article 47 of the Charter of Fundamental Rights of the European Union, everyone whose rights and freedoms guaranteed by the law of the Union are violated has the right to an effective remedy before a tribunal. Consumer satisfaction does not necessitate such a right. 2000 O.J. (L 364) 20. 
Especially in today's ADR world, parties' interests are widely held in higher esteem than their legal positions. ${ }^{62}$ This is because interests are perceived to be related to the future, which seems to matter more than succeeding in court, i.e., successfully enforcing a right with respect to an issue relating to or having happened in the past. ADR proponents point out that parties to a conflict want to save time and transaction costs, eliminate litigation risk, and maintain the relationship with their respective counterparts. ${ }^{63}$ The latter aspect often plays an important role when parties decide to attempt mediation instead of bringing suit. However, the nature of the respective dispute has a considerable impact on the importance of this pro-ADR argument. The preservation of relationships is hardly relevant for consumers and thus, does not push in the direction of alternative dispute resolution in B2C conflicts. As long as they transact on a sufficiently competitive product or services market, consumers can immediately turn to other traders and will have no interest at all in maintaining a sound relationship with their counterparts.

This is especially true for distance contracts. Whereas in contracts among locals or within a small industry, parties might not want to burn bridges, a consumer can shop from an almost unlimited number of traders around the world. Thus, she can easily walk away at no cost; it is first and foremost the trader who is interested in a harmonious business-consumer relationship. This is all the more true as the vast majority of consumer disputes arise from alleged malperformance by the trader. ${ }^{64}$ In this case, consumer confidence will have already been lost in most cases, and the customer will rarely ever contract with the business again. Hence, as long as the further interests of the consumer-a speedy and low-cost process at little risk - are met, consumer protection will mean enforcing consumer rights rather than reaching a consensus between business and consumer or realizing some other diffuse idea of consumer satisfaction.

62 The importance of the parties' interests for value creation in conflict resolution has been stressed primarily by Fisher, Ury and Patton. See FiSHER ET AL., supra note 40. See also Chris Provis, Interests vs. Positions: $A$ Critique of the Distinction, 12 NegOT. J. 305 (1996) (critical on the differentiation between interests and positions).

${ }^{63}$ See Pablo Cortés, The Potential of Online Dispute Resolution as a Consumer Redress Mechanism, SSRN (July 6, 2007), http://ssm.com/abstract_id=998865; see Fahimeh Abedi \& Sakina S. A. Yusoff, Consumer Dispute Resolution: The Way Forward, 2 J. GLOBAL MGMT. 204 passim (2011).

64 EUROSTAT, CONSUMERS IN EUROPE 54 (2009). In 2011, one out of five consumers experienced a delay in delivery, and one out of twenty consumers a complete failure of delivery from a distance contract with a contractor in the consumer's own country. See FLASH EUROBAROMETER 332, supra note 11, at 92. 
This argument is supported by research on the social costs and benefits of litigation. Beyond the individual interests of consumers, the social function of enforcing their rights is that only then will those rights be fully honored by businesses. In other words, in case of suboptimal consumer rights enforcement, these rights will be diluted and hence will be the proper incentive for traders to respect them. ${ }^{65}$ If a trader anticipates that, should she breach a contract, some alternative dispute resolution scheme will be in place leading to a compromise solution that does not fully compensate the consumer for the harm suffered, breach will occur even if it is inefficient. Hence, consumer dispute resolution systems should aim at full enforcement of substantive consumer rights. ${ }^{66}$ Further, the enforcement of rights should be made public to establish precedential value. ${ }^{67} \mathrm{~A}$ financial institution, for example, that violates fiduciary duties towards consumers in selling products to them that earn the institution a commission, ${ }^{68}$ should be held accountable in all relevant cases. The institution's liability should not be limited to compensating an individual consumer who eventually dared to pursue her rights. ${ }^{69} \mathrm{An}$ individual enforcement level of significantly less than $100 \%$ can be tolerated only if it is compensated by complementary enforcement mechanisms, including, for example, unfair competition suits by competitors or forceful collective redress by consumer organizations.

Consequently, even though it is certainly true that consumers are primarily interested in getting good value for money and not in enforcing the law at all costs, a dispute system for B2C conflicts should, in principle, be

${ }^{65}$ HORST EIDENMÜLLER, VERTRAGS- UND VERFAHRENSRECHT DER WIRTSCHAFTSMEDIATION 7 (2000); Steven Shavell, The Social Versus the Private Incentive to Bring Suit in a Costly Legal System, 11 J. LEGAL STUD. 333 (1982); Steven Shavell, The Fundamental Divergence Between the Private and the Social Motive to Use the Legal System, 26 J. LEGAL STUD. 575 (1997).

${ }^{66}$ A necessary caveat to the statement in the text is that full enforcement of substantive consumer rights is warranted on efficiency grounds only if those rights are efficient in the first place-which is certainly not the case with respect to the existing European consumer rights acquis in its totality. See supra section II.A.

${ }^{67}$ Owen M. Fiss, Against Settlement, 93 YALE L. J. 1073 (1984); Deborah R. Hensler, Our Courts, Ourselves: How the Alternative Dispute Resolution Movement Is Re-Shaping Our Legal System, 108 PENN ST. L. REV. 165 passim (2003).

${ }^{68}$ For consistent case law by the Bundesgerichtshof [BGH] [Federal Court of Justice] on this issue see BGH Feb. 12, 2004, BGHZ 158, 110; BGH Dec. 19, 2006, BGHZ 170, 226; BGH July 19, 2011, 64 NEUE JURISTISCHE WOCHENSCHRIFT [NJW] $2011,3227$.

${ }^{69}$ On the case of Crédit Suisse, see Martin Engel, Failure at the Lower Levels, SSRN (Sept. 14, 2011), http://ssrn.com/abstract_id=1927238. 
rights-based. ${ }^{70}$ Consumer rights, if honored, delineate cases in which consumers do indeed get good value for money. By contrast, alternative dispute resolution procedures for B2C conflicts that are primarily aimed at satisfying the interests of the parties will usually produce compromise solutions that result in a suboptimal enforcement level, benefitting businesses yet harming consumers. Sure enough, the majority of cases brought to small claims courts today also settle or otherwise do not proceed to judgment. ${ }^{71}$ However, these settlements are usually reached following a clear judicial instruction regarding the merits and risks of the respective cases, thus in the darkest possible shadow of the law. ${ }^{72}$ Hence, the outcome of small claims court's proceedings is rights-based regardless of whether a judgment is delivered or not.

A further consequence of this assessment relates to the qualifications of persons that are competent to administer rights-based processes. Clearly, only trained jurists can be entrusted with this job. If the goal of the process is rights enforcement, only legal professionals are in a position to do justice to this goal.

\section{Due Process Values}

Apart from the enforcement of substantive consumer rights, several due process values have emerged from the laws of civil procedure of many Member States that are reflected in primary and secondary EU law and thus belong to the "procedural acquis" of the EU. ${ }^{73}$

Among these values are the neutrality of any involved third party or dispute resolution provider, adequate competence of such party regarding the respective resolution standard - which might be substantive consumer law-

${ }^{70}$ Hence, we strongly disagree with Christopher Hodges, Iris Benöhr \& Naomi Creutzfeldt-Banda, who wish to "go beyond the legal standards" and base decisions on codes of business practice, faimess, or equity. However, they also say that their "position is somewhat confused." See CHRISTOPHER HODGES ET AL., CONSUMER ADR IN EUROPE 412 (2012).

71 See, e.g., MINISTRY OF JUSTICE, supra note 22; DESTATIS, supra note 21, at 18.

72 The term "shadow of the law" was introduced by Robert H. Mnookin \& Lewis Kornhauser. See Robert H. Mnookin \& Lewis Kornhauser, Bargaining in the Shadow of the Law: The Case of Divorce, 88 YALE L.J. 950 (1979).

${ }^{73}$ See Torbjörn Andersson, Harmonization and Mutual Recognition, in ENFORCEMENT AGENCY PraCtice IN EuROPE 245, 245-46 (Mads T. Andenæs, Burkhard Hess \& Paul Oberhammer eds., 2005); Burkhard Hess, Improving the Interfaces Between Arbitration and European Procedural Law, LES CAHIERS DE L'ARBITRAGE [PARIS J. INT'L ARB.] 17 (2010) (Fr.). 
and her accountability. Accountability, here, is understood as referring to the responsibility of the dispute resolution entity for the results achieved and, as the case may be, the reversibility of decisions. If a decision hinges on the interpretation of European law, accountability involves referring a case to the European Court of Justice (ECJ). This indirectly ensures decision quality and uniform application of consumer law throughout the whole of the European Union.

In addition, accessibility of the relevant procedure is of increasing importance. Dispute resolution mechanisms must be easy to initiate, simple to conduct, available at no or low cost for consumers, etc. If such mechanisms involve large amounts of paperwork, a lengthy procedure drawn out over several months, and a disproportionately high cost to the consumer (e.g., $€ 50$ for the enforcement of a $€ 100$ claim), chances are high that the consumer will not pursue his claim.

The above-mentioned principles and values might be regarded as rules of law only applying to the judiciary in its traditional sense. However, since handling consumer conflicts along consumer rights will be widely perceived as a public task, it is paramount that legislators obey these due process values regardless of how the concrete dispute system eventually takes shape.

\section{Access to Justice}

Apart from the enforcement of consumer rights and due process values, a third fundamental principle of justice in dispute systems design is unconditional access to justice. ${ }^{74}$ Especially for typically weak parties, it is essential to have the right to be heard in court ${ }^{75}$ and not to be deprived of the possibility to bring suit by the law or by a contractual provision agreed to without proper reflection. ${ }^{76}$

74 This principle is also rooted in Art. 6(1) of the European Convention on Human Rights. European Convention on Human Rights art. 6, June 1, 2010. See Gralf-Peter Calliess, Online Dispute Resolution: Consumer Redress in a Global Market Place, 7 GERMAN L. J. 647, 647-48 (2006); Pablo Cortés, Developing Online Dispute Resolution for Consumers in the EU: A Proposal for the Regulation of Accredited Providers, 19 INT'L J. L. \& INFO. TECH. 1, 4-6 (2011).

${ }^{75}$ Hence, we understand justice as being provided by the state by conceptual necessity. By contrast, Justin Malbon believes that justice can also be supplied by out-ofstate courts. Justin Malbon, Consumer Complaints, in CONSUMER LAW AND POLICY IN Australia AND NEw ZEALAND 339, 358 (Justin Malbon \& Luke Nottage eds., 2013).

${ }^{76}$ See European Union Agency for Fundamental Rights, Access to Justice in Europe: An Overview of Challenges and Opportunities passim (2011). For the respective discussion in the United States, see Richard M. Alderman, The Future of Consumer Law 
Access to justice is particularly important where businesses are generally allowed to unilaterally propose terms and conditions to the contract in the fine print. Since court proceedings entail unwanted publicity and may lead to disadvantageous precedents from the businesses' perspective, traders might try to exclude legal recourse in their standard business conditions and restrict complaints to alternative dispute resolution. Even though a consumer signs a contract indicating that she has read and accepts the general terms and conditions, it is commonly recognized that this is no meaningful form of consent; nobody truly studies these clauses in advance of signing. Hence, consumers also typically do not wish to waive their right of access to justice because they happen to have signed a contract purporting a waiver of that right. However, if they later find themselves in an alternative dispute resolution procedure, they are prevented from exactly such access, at least for as long as the procedure lasts or as long as they cannot terminate it. ${ }^{77}$

\section{B. Efficiency Criteria}

Apart from questions of justice, efficiency plays an important role in modern dispute systems design. ${ }^{78}$ Efficiency means maximizing social welfare on a cost/benefit basis. ${ }^{79}$ On the benefits side, fully enforcing consumer rights is, as already discussed, not only a justice issue but also mandated on efficiency grounds. Further, conflict resolution procedures differ in how well they protect a party's reputation, which secures future

in the United States-Hello Arbitration, Bye-Bye Courts, So-Long Consumer Protection, SSRN-Univ. OF Hous. Pub. L. \& Legal TheORY Series (Sept. 19, 2007), http://ssrn.com/abstract_id=1015517.

${ }^{77}$ Hesitant, but generally open to dispute resolution clauses in standard terms, LISA K. HofMEISTER, ONLINE DisPute RESOlution BEI VERBRAUCHERVERTRÄGEN 326 (2012).

78 LAWRENCE SUSSKIND \& JEFFREY CRUIKSHANK, BREAKING THE IMPASSE: CONSENSUAl APPROACHES to Resolving PUBlic Disputes 21-26 (1987). See CATHY A. Costantino \& Christina S. Merchant, Designing Conflict MANAgEMENT SySTEMS: A Guide to Creating Productive and Healthy ORganizations 171-72, 194-96 (1995); Stephanie Smith \& Janet Martinez, An Analytic Framework for Dispute Systems Design, 14 HARV. NEGOT. L. REV. 123 passim (2009); Orna Rabinovich-Einy \& Ethan Katsh, Technology and the Future of Dispute Systems Design, 17 HARV. NEGOT. L. REV. 151 passim (2012).

${ }^{79} \mathrm{See}$ Efficient, OXFORDDICTIONARIES.COM, http://oxforddictionaries.com/ definition/english/efficient (last visited Mar. 28, 2014) (referring to maximum productivity). See also Amartya Sen, The Concept of Efficiency, in CONTEMPORARY IsSUES IN ECONOMICS 196 (Michael Parkin \& Avelino R. Nobay eds.,1973); HORST EIDENMÜLLER, EFFIZIENZ ALS RECHTSPRINZIP 41 passim (3d ed. 2005). 
business. This, however, does not imply that processes and results should be kept confidential. First, as already discussed, protecting one's reputation usually is important only for traders because, other than businesses which are regularly rated in review sites, consumers rarely "carry around" a negative reputation as a contracting party. ${ }^{80}$ Second, securing future business is not an end in itself. On efficiency grounds, market participants who generate business only by engaging in dubious or even fraudulent practices should rather be forced to leave the market.

On the costs side, the law generally should reduce transaction costs and thereby facilitate trade. ${ }^{81}$ Conflict resolution costs comprise the direct system costs associated with the procedure and its administration and supervision, regardless of whether these are borne by both parties, one of the parties, or a third party, such as the general tax payer (e.g., in case of legal aid awarded to one of the parties). Moreover, there are usually substantial opportunity costs, most notably the time that parties must invest in the process. Procedural efficiency is increased where dispute resolution is not only free of unnecessary cost drivers and redundant complexity, but also fast and reliable. ${ }^{82}$ Together with the tenet of a rights-based solution, this provides the background for a coherent model for a consumer rights dispute system in B2C transactions.

${ }^{80}$ Even where generating negative customer reputation is feasible, market organizers step back. An interesting example of this phenomenon is the feedback rating on eBay. Since 2008 , sellers can only give positive feedback to buyers, whereas buyers can still rate a business negatively. An exception to this asymmetric policy is creditreporting schemes, which allow banks to determine whether a potential customer has a low creditworthiness.

81 This recommendation is rooted in the Coase Theorem. See Ronald Coase, The Problem of Social Cost, 3 J.L. \& ECON. 1 (1960); EIDENMÜLLER, supra note 79, at 63; Calliess, supra note 74 , at 658 .

82 On the importance of technology in saving procedural costs, see David A. Larson, "Brother, Can You Spare a Dime?" Technology Can Reduce Dispute Resolution Costs When Times Are Tough and Improve Outcomes, 11 NEv. L.J. 523 (2011). It is, however, not a necessity that the procedure be free for consumers; contrary to the opinion of Zheng Tang, this can even cause perverse incentives for the consumer. Zheng Tang, An Effective Dispute Resolution System for Electronic Consumer Contracts, 23 COMPUTER L. SECURITY REP. 42, 48 (2007). 


\section{A MODEL FOR A CONSUMER RIGHTS DISPUTE SYSTEM IN B2C TRANSACTIONS}

Against this background, a sound normative model for a consumer dispute system would be comprised of a low-entry initiation mode, a simple but rights-based resolution procedure, the observance of due process standards, and the quick enforceability of results.

\section{A. Initiation}

Initiation of the dispute resolution procedure must be comprehensible to the "average consumer" with modest means and without the assistance of a lawyer. Currently, the best way to realize this is an online standard complaint form that an aggrieved individual can complete on her own by entering her basic data and the reasons for the complaint. The complaint form must not be complex; it is to collect only the most fundamental facts and allegations of the case. It should further involve the capability to upload documents to support the alleged claim.

The value of this kind of complaint form essentially depends on its actual accessibility to the consumers. This fundamentally means that the average consumer should know about the chance to initiate dispute resolution in this way. This in turn presupposes sufficient information, not only from state agencies or consumer organizations, but also from the involved trader himself.

\section{B. Resolution Procedure}

The core model procedure of consumer dispute resolution would begin with an asynchronous online exchange between both parties aimed at resolving the issue through plain communication. The trader should be given the possibility to respond to the consumer's argument and to upload relevant documents on his part within ten business days. Still, the complexity of the process should be limited. A well-structured online tool that contrasts the opinions of both parties and accentuates shared views as well as disagreements can help keep the conflict matter manageable. ${ }^{83}$

${ }^{83}$ A good, although not perfect tool is the recently modernized Juripax technology. See JURIPAX: TECH. FOR EARLY DISP. RESOL., http://juripax.com/EN/software.php (last visited Mar. 28, 2014). 
It is debatable whether the model procedure should allow for the taking of evidence. To include such procedural steps means to considerably increase the complexity of the system at the risk of the consumer no longer finding her way through the process. Also, evidentiary issues rarely arise in practice, as most cases can and will be resolved by acknowledgement, waiver, or another form of settlement. On the other hand, excluding questions of proof from the model procedure might provoke abusive consumer complaints with customers opportunistically alleging business malperformance in order to compenșate for their own mistakes. A compromise in this regard would be a procedure that does not include evidentiary issues but that allows the case to be referred to a different, more elaborate process if the conflict is escalated to a level on which issues of proof become decisive.

\section{Enforcement and Publication}

Eventually, the outcome of the dispute resolution should be binding at least on the business and also easily enforceable. Even for small claims, consumers must be able to mandate a marshal to collect the debt with the full force of the public enforcement machinery, if necessary. Only then does the process give both parties a strong incentive to comply with the procedural outcome.

Apart from that, if the outcome of the dispute resolution scheme is not a settlement but the decision of a third party, it should be published so that other traders and consumers can adjust their behavior to the new precedent. The publication of results is also important because it helps dispute resolution providers arrive at consistent decisions that do not contradict each other. Finally, it also serves to vindicate crucial public policies and principles beyond the private interests of the parties, such as antitrust laws, which are easily violated in non-public settlements. ${ }^{84}$

This brief sketch of a model consumer conflict resolution procedure raises the question of where this dispute system should ideally be set up, i.e., who should administer it. Which entity is best equipped to establish a rightsbased, low-cost dispute resolution procedure that observes due process standards and can lead to an easily enforceable and public award? The answer to this question is simple: It is the state. The model described is a modern court proceeding for small claims in B2C disputes. It is the public courts who are in a unique position to enforce consumer rights. Failure in the modernization of civil procedure in many Member States should not lead the

${ }^{84}$ Hensler, supra note 67,196 (calling this "achiev[ing] social change"). 
legislature to remove public courts' involvement in small claims procedures and to allocate original tasks of the judiciary to private service providers. ${ }^{85}$

\section{A CRITIQUe OF THE RECENT EU LEGISLATION ON CONSUMER ADR AND ODR}

Against this background, the recent EU legislation on consumer ADR and ODR raises major concerns as to the enforcement of mandatory consumer rights, the compliance with fundamental values of due process, and the efficiency (welfare) effects associated with it.

\section{A. Visions for Viable Consumer Dispute Resolution}

The EU model for a Union-wide consumer dispute resolution system is composed of local dispute resolution entities established by the Member States in accordance with the Directive on Consumer ADR and an online clearinghouse set up by the EU itself following the Regulation on Consumer ODR. The underlying vision of this model is to build a new civil justice system not based on courts, but rather, on private or semi-private settlement and decision bodies operated by chambers of commerce, trade associations, consumer organizations, or entirely private service providers. ${ }^{86}$ The EU aims to achieve full regional and sector coverage of those services throughout all Member States so that consumers can consistently choose a cheap and accessible alternative to the formalized small claims procedure in public courts. ${ }^{87}$ The EU envisions a collaborative relationship between consumers,

85 This problem is not sufficiently reflected in the otherwise prudent proposal by Pablo Cortés. See Pablo Cortés, Developing Online Dispute Resolution for Consumers in the EU: A Proposal for the Regulation of Accredited Providers, 19 INT. J. L. INFO. TECH. 1 passim (2011).

${ }^{86}$ See Directive on Consumer ADR, supra note 6, at 64 ("system of redress"); Id. at 68 ("ADR procedures should not be designed to replace court procedures"). See also Regulation on Consumer ODR, supra note 6, at 3. Currently, about half of the existing ADR entities notified to the European Commission are based in Germany. However, German ADR entities are less focused on consumers, and thus, play a less important role than the highly frequented ADR bodies in other countries, e.g., the Financial Ombudsman in the United Kingdom handling alone about one-fifth of about 0.5 million cases per year in the EU; ALLEWELDT ET AL., supra note 42, at 13.

${ }^{87}$ Directive on Consumer ADR, supra note 6, at 66, 71. 
traders, and regulators, which might in the future even impose an obligation to use the alternative system before bringing suit. ${ }^{88}$

The EU vision is not the one and only alternative. It is also conceivable, and indeed quite realistic, for there to be massive improvements in the existing small claims court systems in the Member States. Such improvements would, inter alia, result in more efficient court proceedings and the use of modern technology for case filings as well as for the conduct of hearings. Legislators might also consider the use of new public enforcement mechanisms, such as collective redress, punitive damages, consumer advocates, ${ }^{89}$ nauseas and similar measures, to make up for individual enforcement deficits. Indeed, the EU now, at least very cautiously, recommends that Member States introduce collective redress schemes. ${ }^{90}$ Finally, court modernization could be pushed and supported by innovation in private dispute resolution services. Such services could and should coexist beneficially with the public courts. ${ }^{91}$

\section{B. Adherence to Fundamental Principles of Procedural Quality}

Whereas the latter vision fully respects and adheres to fundamental principles of procedural quality, the recent EU regulation does so only to a very limited extent.

\section{Justice}

Given that consumer justice demands rights-based proceedings, mandatory consumer rights should be enforced by judges or other legal

88 Christopher Hodges, Consumer $A D R$ in Europe, 11 ZEITSCHRIFT FÜR KONFLIKTMANAGEMENT 195, 196 (2012).

89 See Luke Nottage, The New Australian Consumer Law: What About Consumer $A D R$ ?, 9 QUTLJJ 176, 192 (2009); CONSUMER LAW AND POLICY IN AUSTRALIA AND NEW ZEALAND 350 (Justin Malbon \& Luke Nottage eds., 2013).

90 See Directive on Consumer ADR, supra note 6, at 66. See also Commission Recommendation 2013/396, Common Principles for Injunctive and Compensatory Collective Redress Mechanisms in the Member States Concerning Violations of Rights Granted Under Union Law, 2013 O.J. (L 201) 60 (EC), available at http://ec.europa.eu/ justice/civil/files/c_2013_3539_en.pdf.

91 Typically, private adjudication schemes will follow economic considerations rather than public court procedures. See William M. Landes \& Richard A. Posner, Adjudication as a Private Good, 8 J. LEGAL STUD. 235 (1979). This, however, does not necessarily weaken the case for the courts; it only emphasizes the function of private providers to serve as a potential (technological) role model. 
professionals who possess a keen understanding of the law and operate on the basis of fundamental due process principles. In stark contrast, the EU regulation requires natural persons in charge of consumer ADR to only have a general understanding of the law. ${ }^{92}$ This is an extremely vague standard. It is also clearly not a qualification that supports the full enforcement of consumer rights. ${ }^{93}$ Rather, it aims at raising consumer satisfaction-whatever that means and however it is measured-under the guise of consumer protection. ${ }^{94}$

It is also questionable how Member States will effectively monitor the performance and neutrality of dispute resolution providers if they decide or settle disputes according to criteria that have not been transparently established beforehand. ${ }^{95}$ Any result may be justified or rationalized as increasing consumer satisfaction. The existing ombudsman entities employ numerous employees whose qualification to handle complicated legal issues is doubtful. Whereas the head ombudsman is often a renowned jurist, ${ }^{96}$ there is no transparent mechanism to ensure appropriate staffing. ${ }^{97}$ Further, enforcing private providers' decisions in contested cases will certainly not be

92 See Directive on Consumer ADR, supra note 6, at 72.

93 However, Christopher Hodges argues that the "advantage of ADR mechanisms is that they are essentially outside national court systems." Hodges, supra note 59, at 205, 226. This is a distinct disadvantage if the mechanism in question is a rights-based dispute resolution procedure that is administered by non-legal providers. $I d$.

94 Against the background of the UNCITRAL ODR Project, Ronald Brand argues that access to courts is not access to justice and that only an easily accessible ODR scheme could offer "the hope of real justice." Brand, supra note 52 at 11. Similarly, Julia Hörnle sees "greater access to justice" through out-of-court ODR. JULIA HöRNLE, CROSSBORDER INTERNET DISPUTE RESOLUTION 89 (2009). This understanding of justice seems questionable as it reloads the concrete and traditional idea of justice with the abstract and vague standard of consumer satisfaction.

95 Close monitoring of the qualification of neutrality is especially important where the respective dispute resolution mechanism was not chosen by both parties. See Felix Steffek et al., Guide for Regulating Dispute Resolution (GRDR): Principles and Comments, in REgUlating DisPUTE RESOlUTION: ADR AND ACCESS TO JUSTICE AT THE CROSSROADS 13, 26 (Felix Steffek \& Hannes Unberath eds., 2013).

96 For example, the Danish Consumer Ombudsman was previously Head of the Property Law Division in the Danish Ministry of Justice; the German Insurance Ombudsman previously served as President of the German Federal Supreme Court.

${ }^{97}$ It is quite telling that the "Competency Model" set out by the UK Legal Ombudsman splendidly rolls out numerous factors of the staff's competencies on 11 closely typed pages-without mentioning legal skills at all. See Competency Model, LEGAL OMBUDSMAN (Mar. 2010), http://www.legalombudsman.org.uk/downloads/ documents/job_docs/OLC_Competency_Model.pdf. 
easier and often will be more difficult than enforcing a small claims court judgment. ${ }^{98}$ Finally, the new EU system appears to violate core procedural values such as the right to be heard in court, the possibility to appeal, and the public accountability of decision makers. ${ }^{99}$ Whereas the ECJ currently ensures consistent consumer law application throughout the whole EU, referring cases to $A D R$ entities creates significant fragmentation as to the interpretation and application of consumer rights. The consumer dispute system designed by the EU promises effective consumer protection but will yield hardly more than effective consumer sedation.

\section{Efficiency}

In terms of procedural efficiency, the EU scheme indeed facilitates complaint filing by making use of modern communication technology. It also aims at offering a fast-track procedure that is simple to initiate and easy to comprehend, even for the average consumer. Moreover, traders who participate in the alternative dispute resolution scheme have to provide information to competent $A D R$ entities so that factual obstacles to the procedure are reduced.

At the same time, the regulatory burden for setting up the EU mechanism is huge. Public authorities in all Member States will have to supervise private ADR providers, their expertise, independence, impartiality, and effectiveness. The EU itself must not only build an online platform for conflict allocation; it must also create an online case management tool for a comprehensive electronic handling of cases. Hence, a new court-like system will emerge next to the small claims courts in every Member State. This will result in an inefficient duplication of resources. It would be much more prudent and efficient to modernize the existing judicial infrastructure in the Member States and provide a court-run, electronic small claims procedure based on the model sketched above.

This rival vision of improving the existing court system builds on the independence and expertise of judges instead of setting up a completely new infrastructure that would be difficult to monitor. It also facilitates

98 It is, however, not impossible that decisions by private dispute resolution providers come with higher voluntary compliance. See Hodges, supra note 88, at 197.

99 The example of the Irish Financial Services Ombudsman shows that accountability of the ADR entities and reversibility of decisions does significantly lower the desirability of a scheme: In 2010, only about one out of three complaints was eventually decided by the Ombudsman. See FinANCIAL SERVICES OMBUDSMAN, FinANCIAL SERVICES OMBUDSMAN ANNUAL REPORT 2010, 17 (2011). 
competition between state and private proceedings and uses this competition as a discovery process: 100 if private dispute resolution providers come up with innovative (technical) solutions, these elements may later be adopted in the state proceedings. Such competition is, unfortunately, stifled by regulating consumer $\mathrm{ADR}$ and ODR in the way the EU currently does.

\section{Access to Justice}

A further, but no less pressing, aspect is compliance with the fundamental right of access to justice. Art. 1 of the Directive on Consumer ADR emphasizes that the use of alternative dispute resolution be voluntary for the consumer and should not prevent her from exercising her right of access to the judicial system. Similarly, Art. 10(1) states that Member States:

[S] hall ensure that an agreement between a consumer and a trader to submit complaints to an ADR entity is not binding on the consumer if it was concluded before the dispute has materialized and if it has the effect of depriving the consumer of his right to bring an action before the courts for the settlement of the dispute. ${ }^{101}$

Prima facie, this suggests that consumers cannot be pulled into an ADR procedure in the general terms and conditions of a trader. However, on a closer look, the issue is not that simple. Recital 45 of the ADR Directive makes it quite clear that the wording in Art. 10(1) only relates to ADR procedures that permanently take the case out of the state court system such as arbitration: "In cases where a dispute could not be resolved through a given ADR procedure whose outcome is not binding, the parties should subsequently not be prevented from initiating judicial proceedings in relation to that dispute."102 In other words, a mediation or conciliation clause in a trader's general terms and conditions would not fall foul of the Directive on Consumer ADR.

Sure enough, the Directive 93/13/EEC on unfair terms in consumer contracts includes provisions against unfair small print in consumer contracts. Art. 3(3), Annex (1)(q) suggests that a clause may be regarded as unfair if it excludes or hinders the consumer's right to take legal action. Nevertheless, arbitration clauses are not necessarily invalid because legal

100 The value of competition as a "discovery process" was first highlighted by Friedrich von Hayek. FrIEDRICH A. vON HAYEK, FREIBURGER STUdIEN 249 (1969).

101 Directive on Consumer ADR, supra note 6, at 75.

102 Id. at 68 . 
action is broadly understood in Annex (1)(q) to mean any procedure that is "covered by legal provisions," and arbitration surely will, in most cases, be covered by such provisions. It is a question of the applicable national consumer protection law whether such a clause is invalid or not. ${ }^{103}$ Most Member States' laws guard the consumer against unexpected arbitration clauses and deem them void. ${ }^{104}$ Against this background, the new Directive on Consumer ADR does not provide additional protection.

Temporary action waivers such as waivers associated with a mediation or other ADR procedures not binding on the consumer are a different matter, however. In most Member States, these waivers are unobjectionable even if included in the general terms and conditions of a trader. Moreover, they do not violate Annex (1)(q) of Directive 93/13/EEC as consumers maintain the right to bring suit once alternative dispute resolution has failed. ${ }^{105}$

However, the said waivers are hardly less problematic: they urge consumers to try alternative dispute resolution, ${ }^{106}$ and even though consumers may initiate adversarial proceedings thereafter, they will not pursue such proceedings in most cases. As every mediation practitioner will confirm, it takes a lot of stamina and determination to fight a 50/50

103 Case C-168/05, Claro v. Centro Móvil Milenium SL, 2006 E.C.R. I-10421, (concerning a mobile phone contract with an arbitration clause); Gerhard Wagner, Keine Präklusion des Einwandes der Nichtigkeit einer Schiedsvereinbarung wegen Missbräuchlichkeit in Verbraucherverträgen, 5 GERMAN ARB. J. 49 (2007) (annotation). On mandatory binding arbitration in consumer disputes, see Elizabeth G. Thornburg, Going Private: Technology, Due Process, and Internet Dispute Resolution, 34 U.C. DAVIS L. REV. 151 passim (2000).

${ }^{104} \mathrm{See}$ Bundesgerichtshof [BGH] [Federal Court of Justice] Jan. 13, 2005, NEUE JURISTISCHE WOCHENSCHRIFT [NJW] 1125, 2005 (Ger.). In Germany, for example, ZPO [CODE OF CIVIL PROCEDURE] § 1031(5) provides that consumer arbitration clauses must be stipulated separately in order to be valid. The English Regulation from 1999 implementing Council Directive 93/13, 1993 O.J. (L 95) states that binding arbitration clauses shall be void except if negotiated individually. See Art. 36(2) Codice dei Consumatori (It.), available at http://www.andec.it/public/80\%2004-Codice_del\%20 Consumo\%20_En.pdf?idPP $=1365$ \&idPulsante $=861$ (Italy goes one step further by declaring the respective standard business conditions void even if it was negotiated individually).

105 Case C-317/08, Alassini v. Telecom Italia SpA, 2010 E.C.R. II-3989 (concerning contracts for the provision of telephone services, including a clause making reference to the court proceedings conditional upon an attempt to settle the dispute out of court). See, e.g., Gerhard WAGNER, ProzessverTRÄGE 445, passim (1998); EIDENMÜLlER, supra note 65 , at 14 passim.

${ }^{106}$ Felix Steffek et al., supra note 95, at 13, 29 (postulating the principle of "initiation control" which is hardly compatible with the urge towards an out-of-court procedure). 
settlement proposal achieved as the outcome of a consensual and often laborious procedure-stamina and determination that the average consumer typically does not have. ${ }^{107}$ And even if the consumer completely loses out in an ADR procedure, she will likely be prevented from going to court. After all, if one "expert" already told her that she has no case, why would she go through all the hassle and costs again, only to be told a second time?

At the same time, this dispute system is highly attractive for businesses. By pushing cases into ADR schemes, they can minimize the risk of negative publicity associated with public proceedings that highlight illegal commercial practices. The most active and stubborn consumers will be paid off - in secrecy, and possibly only partially. No effective sanctions will be administered in the great mass of the cases. At the same time, advocating ADR schemes as effective consumer dispute resolution tools appears to be an accommodating policy position. It significantly reduces the political pressure to introduce public collective redress schemes in the European Union that would effectively address the issue of mass damages in consumer contracts-apparently the nightmarish litigation risk of businesses. ${ }^{108}$

This is all the more problematic if ADR entities predominantly deliver judgments or opinions in favor of traders-as they frequently do. ${ }^{109}$ It is no wonder given that these entities are primarily financed by businesses. Even with these financial arrangements, ADR entities publicly stress their independence and neutrality, and there certainly is no strong empirical support thus far for the assumption that financing schemes might lead them to systematically discriminate against consumers. However, the bad taste prevails, especially where businesses own $^{110}$ a process of consumer rights

107 See Herbert Roth, Bedeutungsverluste der Zivilgerichtsbarkeit durch Verbrauchermediation, 68 JURISTENZEITUNG 637, 643 (2013).

108 Am. Express Co. v. Italian Colors Rest., 133 S. Ct. 2304 (2013) (confirming the validity of arbitration clauses in consumer contracts in the United States). See also Peter L. Murray, Die Flucht aus der Ziviljustiz, 11 ZEITSCHRIFT FÜR ZIVILPROZESS INT'L 295, 300 (2006).

109 See OMBUDSMANN FÜR VERSICHERUNGEN, JAHRESBERICHT 2012, 89 (2013) (reporting that only $36 \%$ of consumer complaints against businesses, apart from life insurance complaints, brought to the German Insurance Ombudsman were completely or partly successful. In almost two out of three cases, the consumer completely failed and one out of four complaints was considered improper action and thus dismissed). See also Lord Phillips of Matravers, Alternative Dispute Resolution: An English Viewpoint, 74 ARB. 406, 408 (2008) (saying of compulsory mediation in the UK: "You can take a horse to water, but you cannot make it drink. To which those in favour of compulsory mediation reply, 'yes, but if you take a horse to water it usually does drink."').

110 See Cathy A. Costantino, Second Generation Organizational Conflict Management Systems Design: A Practitioner's Perspective on Emerging Issues, 14 
enforcement. ${ }^{111}$ Also, public courts are an institution, which is perfectly designed according to the principles of autonomous and unbiased decisionmaking. This calls for the judiciary to maintain full sovereignty over the interpretation and application of consumer protection law. To shift jurisdictional responsibilities to private or semi-private providers might improve access to some private form of justice in many Member States; but at the same time it will worsen access to independent public justice in countries with an efficient judiciary. ${ }^{12}$ Public justice, however, serves an important role even where the amounts in dispute are low because with these kinds of disputes, the total societal damage is usually much larger. Just think of an unfair clause in a mobile phone contract that harms millions of customers, but where each individual customer only suffers a loss in the order of $€ 1-€ 10 .{ }^{113}$ To lure consumers into a settlement here is to seriously compromise consumer rights. In other words: If the EU aims at effectively protecting consumers, it should better guard against false settlement. ${ }^{114}$

\section{The Call for the European Union}

If the EU refrained from establishing an alternative small claims civil system, what could instead be done to foster innovative and efficient dispute resolution procedures for consumer conflicts? What does the better role model for the EU itself look like?

In fact, the EU has only a limited capacity to influence the civil procedure laws of its Member States. The principle of conferral laid down in Art. 5(2) Treaty on European Union (TEU) requires a specific legal basis for any action taken by the EU. A harmonization measure regarding civil procedure laws cannot be based on Art. 114 Treaty on the Functioning of the European Union (TFEU) on the establishment and the functioning of the internal market because the special competence of Art. 81 TFEU rules out

HARV. NEGOT. L. REV. 81, 85 (2009) (commenting on ownership of dispute systems to be designed).

111 See Adam B. Kinon, Power Before Interests in Dispute System Design, 17 HARV. NEGOT. L. REV. 273 (2012) (urging for increased awareness of power in dispute systems design in a slightly different context).

112 Roth, supra note 107, at 641. See generally Hodge, supra note 88, at 197.

113 Mulcahy, supra note 59, at 66.

114 This conclusion hints at the well-known article entitled "Against Settlement" by Owen Fiss. See Fiss, supra note 67. 
the application of Art. 114 TFEU.115 Art. 352 TFEU does not allow for the harmonization of civil procedure laws in the Member States either. ${ }^{116}$ Hence, it is first and foremost Art. 81 TFEU, which can serve as a legal basis for harmonizing Member States' civil procedure rules. With respect to other ADR instruments, the EU has thus with good reason solely relied on Art. 81 TFEU, for example, in the case of the European Mediation Directive. ${ }^{117}$ However, this legislative competence of the EU is limited to cross-border cases. This constraint also holds for the conceivable introduction of a European class action. Against this background it is quite telling that the Commission did not even mention a legal basis in the TFEU when it recently recommended the consideration of common principles for injunctive and compensatory collective redress mechanisms in the Member States. 118

Instead of considering measures not provided for in the TFEU, the EU would better act as a role model for the use of electronic infrastructure and similar improvements in small claims courts. A first step in this regard might be to streamline the procedure at the ECJ and the General Court, the two courts of the Court of Justice of the European Union. These courts eat up huge amounts of money from the Member States by using up to 13 judges per case and employing costly offline procedures that involve the presence of persons from many Member States as well as work for legions of interpreters. Furthermore, the EU could technologically update its own ejustice portal, including its small claims procedure. ${ }^{119}$ By modernizing the

115 The ECJ has repeatedly decided that measures that come within the limits of a specific legislative competence cannot be based on Art. 114 TFEU. See Case C-155/91, European Comm'n v. Council, 1993 E.C.R. I-939; Case C-491/01, The Queen v. Sec'y of State for Health ex parte BAT, 2002 E.C.R. I-11543; Case C-411/06, European Comm'n v. Parliament \& Council, 2009 E.C.R. I-7585. See also Stefan Leible \& Ansgar Staudinger, Article 65 of the EC Treaty in the EC System of Competencies, 1 EUR. LEGAL F. 225, 234 (2001) (referring to the principle of subsidiarity, Art. 5(3) TFEU).

116 Case C-436/03, European Parliament v. Council, 2006 E.C.R. I-3733 (clearly stating that Art. 352 TFEU does not allow for such harmonization. Apart from that, the unanimity requirement of Art. 352 TFEU often makes the Commission refrain from even attempting to make use of this legislative competence).

117 See, e.g., Council Directive 2008/52, 2008 O.J. (L 136) 3 (EC) (solely relying on Art. 81 TFEU).

118 Commission Recommendation, supra note 90.

119 Interestingly, the Union's own small claims procedure, established in 2009, is rather an embarrassing role model for the handling of low-value disputes. See FEDERICO ViCARI ET AL., ECC-Net European SMall Claims Procedure RePort 23 (2012) (establishing that only $12 \%$ of the Member States can confirm that more than 5 (!) cases have been initiated since 2009; the remaining Member States report up to five cases or that there are no data available). 
procedures already directly governed by EU law, the EU could set a good example and thereby even free up resources, which the Member States could use to improve the operation of their own small claims courts. The EU also could support and supplement the Member States in their attempts to trim their procedural laws. Such measures can easily be based on Art. 169(2)(b) TFEU. ${ }^{120}$ Member States who today refrain from modernizing their small claims procedures because of lacking resources or legislative lethargy would then be encouraged to follow the lead by the EU and thereby help consumers to effectively pursue their rights.

\section{SUMMARY}

With the Directive on Consumer ADR and the Regulation on Consumer ODR, the EU aims to create a new consumer conflict resolution scheme that satisfies the needs of businesses and consumers more effectively than the small claims courts in the Member States currently do. However, from the perspective of dispute systems design, this policy move is highly problematic. The benefit of easy accessibility of the new system comes with severe flaws:

(i) The new system is not geared towards the effective enforcement of consumer rights. However, less than full enforcement compromises the EU's policy of protecting consumers in $\mathrm{B} 2 \mathrm{C}$ transactions by mandatory substantive provisions. It also leads to inefficient behavioral incentives for traders.

(ii) The new system also compromises due process values. The right to be heard, the right to appeal a judgment, the right to publicly criticize, the right to discuss the ADR procedure and its outcome, and the accountability of the neutral third party-all these are not necessarily guaranteed.

(iii) The new system establishes a comprehensive, quasi-judicial landscape of ADR providers next to the courts. The private providers must be heavily regulated to secure minimum service standards. The transaction costs associated with this are significant. This duplication of resources-public courts and heavily regulated private ADR providers-is inefficient.

(iv) Finally, the new system will de facto prevent consumers from fighting an ADR decision or opinion even if it is non-binding on them. Hence, it is also highly problematic because it reduces access to justice.

The best institution to realize the goals of a rights-based and efficient consumer dispute resolution system is not a private or semi-private provider but the state. It is simply contradictory to craft a comprehensive set of

${ }^{120}$ Iris Benöhr, Alternative Dispute Resolution for Consumers in the European Union, in CONSUMER ADR IN EUROPE 7 (Christopher Hodges et al. eds., 2012). 
substantive and mandatory consumer protection rights and then leave the enforcement of these rights to private or semi-private bodies whose independence and impartiality is questionable and who are staffed not necessarily with trained jurists but with "professionals" who may only have some superficial understanding of the law. Mandatory consumer protection rights attempt to correct market failure. Enforcement of such rights should be entrusted to public courts, not returned to the market. The EU would do much better in modernizing its own courts and proceedings and should work towards a Union-wide consensus for the modernization of small claims courts procedures in all Member States. 
